\title{
Prone positioning of non-intubated patients with COVID-19 - A Systematic Review and Meta-analysis
}

\author{
Authors \\ *Mallikarjuna PONNAPA REDDY ${ }^{1,2}$ MBBS, FCICM, MCTR, DCH, DECMO \\ *Ashwin SUBRAMANIAM ${ }^{2,3}$ MBBS, MMed, FRACP, FCICM \\ Zheng Jie LIM ${ }^{4}$ MBBS \\ Alexandr ZUBAREV ${ }^{2}$ MD, EDAIC \\ Afsana AFROZ ${ }^{6} \mathrm{PhD}$ \\ Baki BILLAH ${ }^{6} \mathrm{PhD}$ \\ Gabriel BLECHER ${ }^{3,5}$ MBBS, PDM, FACEM, CCPU, MSc (Epi) \\ Ravindranath TIRUVOIPATI ${ }^{2,3}$ MBBS, MS, MCh, FRCSEd, MSc, FCICM, EDIC \\ Kollengode RAMANATHAN ${ }^{7,8,9}$ MD, FCICM \\ Suei Nee $\mathrm{WONG}^{7} \mathrm{MSc}$ \\ Daniel BRODIE ${ }^{9,10} \mathrm{MD}$ \\ Eddy FAN ${ }^{11} \mathrm{MD}, \mathrm{PhD}$ \\ Kiran SHEKAR ${ }^{9,12,13}$ FCICM, PhD \\ * Equal contributions
}

\section{Affiliations}

1 Department of Intensive Care Medicine, Calvary Hospital, ACT, Australia

2 Department of Intensive Care Medicine, Peninsula Health, Frankston, Vic, Australia

3 Faculty of Medicine, Nursing and Health Sciences, Monash University, Clayton, Vic, Australia

4 Department of Intensive Care Medicine, Ballarat Health Services, Ballarat, Vic, Australia

5 Emergency Department, Monash Health, Clayton, Vic, Australia

6 Department of Epidemiology and Preventive Medicine, School of Public Health and Preventive Medicine, Monash University, Melbourne, Vic, Australia

7 Yong Loo Lin School of Medicine, National University of Singapore, Singapore.

8 National University Hospital, Singapore

9 Bond University, Gold Coast, Queensland, Australia.

10 Center for Acute Respiratory Failure, New York-Presbyterian Hospital, New York, USA.

11 Interdepartmental Division of Critical Care Medicine and Institute of Health Policy, Management and Evaluation, University of Toronto, Toronto, Canada

12 Adult Intensive Care Services and Critical Care Research Group, the Prince Charles Hospital, Brisbane, Queensland, Australia

13 Queensland University of Technology, Brisbane; University of Queensland, Brisbane, Queensland, Australia

\section{Corresponding author}

Dr Mallikaruna Ponnapa Reddy MBBS FCICM DCH DDU

malli_ponnu@yahoo.co.in

ORCID ID: 0000-0002-4736-2901

Intensive care Specialist, Calvary Hospital Canberra, $+61433678732$

ACT, Australia

Abstract: 249 words

Main text word count: 3117 words 


\section{ABSTRACT}

Purpose: Several studies have reported adopting prone positioning (PP) in non-intubated patients with COVID-19-related hypoxaemic respiratory failure. This systematic review and meta-analysis evaluated the impact of PP on oxygenation and clinical outcomes.

Methods: We searched PubMed, Embase and COVID-19 living systematic review from December $1^{\text {st }}$ 2019 to July $23^{\text {rd }} 2020$. We included studies that reported using PP in hypoxaemic, non-intubated adult COVID-19 patients. Primary outcome measure was the weighted mean difference (MD) in oxygenation parameters $\left(\mathrm{PaO}_{2} / \mathrm{FiO}_{2}, \mathrm{PaO}_{2}\right.$ or $\left.\mathrm{SpO}_{2}\right)$ pre and post-PP.

Results: Fifteen single arm observational studies reporting PP in 449 patients were included. Substantial heterogeneity was noted in terms of, location within hospital where PP was instituted, respiratory supports, frequency and duration of PP. Significant improvement in oxygenation was reported post-PP: $\mathrm{PaO}_{2} / \mathrm{FiO}_{2}$, (MD 37.6, 95\%CI 18.8, 56.5); $\mathrm{PaO}_{2}$, (MD $\left.30.4 \mathrm{mmHg}, 95 \% \mathrm{CI} 10.9,49.9\right)$; and $\mathrm{SpO}_{2}$, (MD 5.8\%, 95\% CI 3.7, 7.9). Patients with a pre-PP $\mathrm{PaO}_{2} / \mathrm{FiO}_{2} \leq 150$ experienced greater oxygenation improvements compared with those with a pre- $\mathrm{PP} \mathrm{PaO}_{2} / \mathrm{FiO}_{2}>150$ (MD 40.5, 95\%CI -3.5, 84.6) vs. 37, 95\%CI 17.1, 56.9). Respiratory rate decreased post-PP (MD -2.9, 95\%CI -5.4, -0.4). Overall intubation and mortality rates were $21 \%(90 / 426)$ and $26 \%$ (101/390) respectively. No major adverse events were reported.

Conclusions: Despite significant variability in frequency and duration of PP and respiratory supports, PP was associated with improvements in oxygenation parameters without any reported serious adverse events. Major limitation being lack of control arm and adjustment for confounders. Clinical trials are required to determine the effect of awake PP on patient-centred outcomes.

Systematic review registration: Registration/protocol in PROSPERO (CRD42020194080).

Keywords: COVID-19, SARS-CoV-2, hypoxaemic respiratory failure, Awake proning, Prone positioning, Oxygenation, Endotracheal intubation 


\section{What is the key question?}

Is the novel approach of prone positioning in non- intubated patients associated with improvement in oxygenation?

\section{What is the bottom line?}

Prone position in non-intubated severe COIVD 19 suffers is associated with improvement of oxygenation while the short- and long-term patient centred out comes in this awake prone patient need more investigation.

\section{Why read on?}

Our study is first of its kind (Systematic review and Meta-analysis) summarising the evidence surrounding the less invasive innovate technique of prone position in non-intubated COVID-19 patients.

\section{Declaration:}

Funding: No funding sources to declare

\section{Conflicts of interest:}

DB reports research support from ALung Technologies, and personal fees from Baxter, Abiomed, and Xenios, as well as an unpaid relationship with Hemovent. EF reports personal fees from ALung Technologies, Fresenius Medical Care, Getinge, and MC3 Cardiopulmonary outside the submitted work. All other authors declare no support from any organization for the submitted work, no competing interests with regards to the submitted work.

\section{Availability of data and material:}

All the data analysed in this study is included in the main article and supplementary files. Additional information that was obtained from some of the studies after contacting the authors is available from the corresponding author on reasonable request.

\section{Authors' contributions:}

KS and AS conceived the study idea and co-ordinated the review process. MR, AS, ZL AZ and KS drafted the review protocol, conducted the systematic review, assisted with data analysis and wrote the initial draft of the manuscript. MR and AS contributed equally. SW assisted with literature search. AZ designed the summary tables. AA and BB conducted the statistical analysis and wrote sections of the 
manuscript. EF made significant contributions to the analysis plan. GB, RT, KR, DB and EF critically evaluated the manuscript and contributed to writing of the manuscript. All authors critically reviewed the manuscript and approved the final version prior to submission.

Take-home message: Prone positioning in non-intubated severe COVID 19 patients demonstrated improvements in their oxygenation. However, significant heterogeneity in of duration and frequency of prone positioning and in other respiratory supports provided limit any further interpretation. Whether this improvement in oxygenation results in meaningful patient-centred outcomes needs testing in clinical trials. 


\section{INTRODUCTION}

Coronavirus disease 2019 (COVID-19), caused by the severe acute respiratory syndrome coronavirus 2 (SARS-CoV-2), mainly affects the respiratory system and can lead to acute hypoxaemic respiratory failure. $0.9 \%$ to $32 \%$ of these patients require admission to intensive care units (ICU) for advanced respiratory support. ${ }^{1-4}$ A surge in critically ill patients with respiratory failure has overwhelmed ICU capacity in many healthcare systems across the world. Studies published during the early phase of the pandemic have showed poor outcomes in invasively ventilated COVID-19 patients. Given a guarded prognosis and significant resource constraints less-invasive, innovative approaches such as prone positioning $(\mathrm{PP})$ of non-intubated patients with hypoxaemic respiratory failure was considered. They were initiated in emergency departments (ED), hospital wards, or in ICUs as an adjunct to conventional oxygen therapies, high-flow nasal cannula (HFNC) and non-invasive ventilation (NIV). ${ }^{56}$

The potential efficacy of PP with hypoxaemic respiratory failure is yet to be meaningfully tested in welldesigned clinical trials. Limited data suggests that PP in non-intubated patients is feasible and is associated with an improvement in oxygenation in patients with respiratory failure. ${ }^{7}$ There have been case reports and cohort studies that report the use of PP of non-intubated patients with COVID-19 during the pandemic. ${ }^{2-10}$ Conceptually, awake PP is relatively less time and resource consuming as compared to PP in intubated patients. Theoretically, they may decrease the risks of adverse events seen in intubated prone patients.

Deteriorating oxygenation despite optimal less-invasive respiratory support ${ }^{11}$ is one of the common triggers for invasive mechanical ventilation. PP improves oxygenation by increasing ventilationperfusion matching by the recruitment of the larger number of alveolar units located in dorsal areas of the lungs. ${ }^{12}{ }^{13}$ Furthermore, in patients with COVID-19, PP may also enable gravity assisted diversion of pulmonary blood flows to dorsal regions in the setting of pulmonary vascular dysregulation and loss of hypoxic pulmonary vasoconstriction response in selected patients. ${ }^{14}$ Thus, the success of PP largely hinges on its ability to reliably and predictably improve oxygenation, which may then subsequently improve the respiratory drive, thereby decreasing the risk of self-inflicted lung injury or respiratory fatigue.

Little is known about the magnitude of the effect of PP on oxygenation and its ability to improve patientcentred outcomes in non-intubated COVID-19 patients. Therefore, we performed this systematic review and meta-analysis to evaluate the effect of PP on oxygenation parameters. Secondary analysis included rates of endotracheal intubation and in-hospital mortality. 


\section{METHODS}

The protocol for this systematic review and meta-analysis was registered with PROSPERO (CRD42020194080). The study was conducted in adherence with the Preferred Reporting Items for Systematic Reviews and Meta-analyses (PRISMA) Statement. ${ }^{15}$

\section{Eligibility criteria}

Studies on laboratory-confirmed SARS-CoV-2 hypoxaemic adult patients $(\geq 18$ years of age) requiring supplemental oxygen who received PP were included. Studies were excluded if (a) they were systematic reviews (b) they did not report on oxygenation parameters (either $\mathrm{PaO}_{2}, \mathrm{SpO}_{2}$ or $\mathrm{PaO}_{2 /} \mathrm{FiO}_{2}$ ) (c) case reports or case series with fewer than 5 patients (to decrease reporting bias). The corresponding authors of a study were contacted for missing information required for the analysis.

\section{Search strategy, Information Sources and Study Selection}

Two authors (MR and AZ) independently searched on PubMed, Embase, Cochrane, Scopus and the COVID-19 living systematic review from December $1^{\text {st }}$, 2019 to July $23^{\text {rd }}, 2020$. COVID-19 living systematic review has a daily-updated list of pre-print and published articles relating to COVID-19 obtained from PubMed, EMBASE, medRxiv and bioRxiv. ${ }^{16}$ The living systematic review was previously used during the Zika virus epidemic ${ }^{17}$ and recently has been validated against an Ovid search relating to COVID-19 ${ }^{18}$. Search terms were "Prone", "Prone Position*” or "Proning" along with "COVID-19"related terms were used within the title and abstract columns of the systematic review list. Our search was further supported by medical librarian search that was carried out independently (SW). A detailed search terms and tools are summarised in Supplementary Table 1. No language restrictions were applied.

\section{Quality Assessment and risk of bias in individual studies}

The Newcastle-Ottawa Scale $(\mathrm{NOS})^{19}$ was used to assess the quality of cohort studies while Joanna Briggs Institute Critical Appraisal Checklist ${ }^{20}$ was used to evaluate case series. Using relevant appraisal tools, each study was objectively evaluated by two reviewers independently (MR and ZL). Any discrepancies in the approval scores were reviewed and resolved by an additional reviewer (AS) (Supplementary Table 2).

\section{Study Outcomes}


The primary outcome was the change in oxygenation (i.e., $\mathrm{PaO}_{2} / \mathrm{FiO}_{2}$ ratio, $\mathrm{PaO}_{2}$ and $\mathrm{SpO}_{2}$ ) following $\mathrm{PP}$. Different variables, such as the saturation of peripheral oxygen $\left(\mathrm{SpO}_{2}\right)$, the partial pressure of arterial oxygen $\left(\mathrm{PaO}_{2}\right)$, and the ratio of $\mathrm{PaO}_{2}$ to the fraction of inspired oxygen $\left(\mathrm{PaO}_{2} / \mathrm{FiO}_{2}\right)$, have been used in the reported studies. We derived the $\mathrm{PaO}_{2}$ from $\mathrm{SpO}_{2}$ and vice versa if they were not reported in studies using the accepted conversion formulae for consistency to analyse the data (Supplementary Table 3). ${ }^{21}$ For mall number of studies an estimation formula was used to convert median to mean values (Supplementary Table 4). ${ }^{22}$ Median was derived for $\mathrm{PaO}_{2}$ in 3 studies, for $\mathrm{SPO}_{2}$ in 5 studies and for $\mathrm{PaO}_{2} / \mathrm{FiO}_{2}$ in 2 studies. Sensitivity analyses for physiological parameters were performed by restricting to studies with sample sizes $\geq 20$.

The secondary outcomes included endotracheal intubation rate and mortality. Major adverse events were defined as cardiac arrest, clinically significant haemodynamic instability or accidental dislodgment of intravenous line following PP. Further subgroup analyses were performed to compare: (1) the primary outcome between patients with pre-PP $\mathrm{PaO}_{2} / \mathrm{FiO}_{2}>150$ and $\mathrm{PaO}_{2} / \mathrm{FiO}_{2} \leq 150$; and (2) the primary and secondary outcomes in patients depending on the location within hospital where PP was initiated (within ICU vs. outside ICU). We also performed an exploratory analysis on the changes in patients' respiratory rate (RR) after PP.

\section{Data Analysis}

Statistical analyses were performed using the statistical software package Stata-Version 16 (Statacorp, USA). Mean (standard deviation [SD]) or median (interquartile range [IQR]) were used for numerical data and proportion for categorical data. We report weighted mean difference (MD) with $95 \%$ confidence intervals (95\%-CI) for physiological parameters and event rates using a random effects model to account for both within-study and between-study variances. ${ }^{23}$ Results were presented in Forest plots. Heterogeneity was tested using the $\chi^{2}$ test on Cochran's Q statistic, which was calculated using $\mathrm{H}$ and $\mathrm{I}^{2}$ indices. The $\mathrm{I}^{2}$ index estimates the percentage of total variation across studies based on true betweenstudy differences rather than on chance. Conventionally, $\mathrm{I}^{2}$ values of 0-25\% indicate low heterogeneity, $26-75 \%$ indicate moderate heterogeneity, and $76-100 \%$ indicate substantial heterogeneity. ${ }^{24}$ A subgroup analysis using different sample sizes was carried out to identify the possible causes of substantial heterogeneity. ${ }^{24}$ Due to concerns of the limited available data we could not pre-specify the exact variables for subgroup analysis. Following data collection, we carried out two subgroup analyses on oxygenation and clinical outcomes-: ICU vs. non-ICU (emergency department [ED], respiratory wards, high dependency units [HDU] $)$ and baseline $\mathrm{PaO}_{2} / \mathrm{FiO}_{2}$ ratio $\left(\mathrm{PaO}_{2} / \mathrm{FiO}_{2} \leq 150\right.$ and $\left.>150\right)$. Symmetry of the funnel plots was evaluated, and the Egger's regression test was used to examine for publication bias. ${ }^{25} \mathrm{~A}$ p-value $<0.05$ was considered significant.

\section{RESULTS}


From 248 studies we identified 15 eligible studies ${ }^{2} 1026-37$ and a total of 449 patients were included in the final analysis (Figure 1) The 15 included studies are summarised in Table 1. The reports originated from 6 countries (China, France, Iran, Italy, USA and UK). 287 patients were men (63.9\%) with a mean age (SD) of 56 (7) years. The patients received PP for a variable duration (median 180 minutes, IQR 37.5-264.75) and this procedure was repeated 1-13 times/day during their hospital stay or until intubation, if it occurred. Data on oxygen therapy provided during PP was reported in 350 patients. 68.9\% (241/350) received NIV, $4.9 \%$ (17/350) on HFNC, 13.7\% (48/350) received oxygen via face mask, $12.6 \%(44 / 350)$ via low-flow nasal cannula. Among the 277 patients for whom $\mathrm{FiO}_{2}$ was reported, 175 (63.2\%) of them received $\mathrm{FiO}_{2}<50 \%, 46(16.6 \%)$ were on $\mathrm{FiO}_{2}$ between 50-70\% and $56(20.2 \%)$ of them received $\mathrm{FiO}_{2}$ $>70 \%$ (Supplementary Table 5).

In the 420 patients for whom data on the location of provision of PP was available, 111 patients (26.4\%) received PP in ICU and 309 (73.6\%) outside ICU (respiratory wards, high dependency units or emergency departments).

\section{Primary outcome:}

The improvements in physiological parameters $\left(\mathrm{PaO}_{2} / \mathrm{FiO}_{2}, \mathrm{PaO}_{2}, \mathrm{SpO}_{2}\right)$ before and after PP are presented graphically in Figure 2.

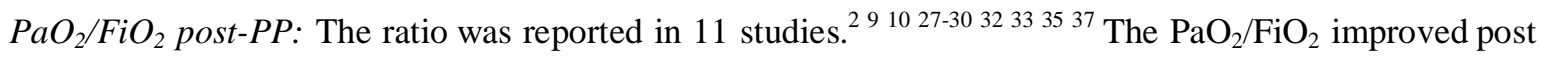
PP (MD 37.6, 95\%-CI 18.8, 56.5; p=0.001) (Figure 3). Heterogeneity persisted despite analysing studies with a sample size of more than 20 patients (4 studies, ${ }^{2} 92833 \mathrm{I}^{2}=97.1 \% \mathrm{p}=0.001$ ) (Supplementary Figure 1). However, the Egger's regression test ruled out publication bias $(\mathrm{p}=0.38)$.

$\mathrm{PaO}_{2}$ post-PP: $\mathrm{PaO}_{2}$ was reported or derived from $\mathrm{SpO}_{2}$ in 13 studies ${ }^{29}$ 26-36 (Figure 3). An improvement in $\mathrm{PaO}_{2}$ was demonstrated following PP (MD 30.4, 95\%-CI 10.9,49.9). The heterogeneity was high $\left(I^{2}=99.8 \%\right)$ (Supplementary Figure 2). Egger's regression test $(\mathrm{p}<0.001)$ suggests, presence of a publication bias. The heterogeneity continued to be high when only studies with more than 20 patients ${ }^{2} 9$ $2628313336\left(I^{2}=99.9 \%\right.$; $\left.=0.001\right)$ were analysed.

$\mathrm{SpO}_{2}$ post-PP: $\mathrm{SpO}_{2}$ was reported in 12 studies. ${ }^{2}{ }^{27-36}$ Improvement in $\mathrm{SpO}_{2}$ (MD 5.8, 95\%-CI 3.7, 7.9; $\mathrm{p}=0.001$ ) was seen across all studies where $\mathrm{SpO}_{2}$ was obtained (Figure 3). However, there was high heterogeneity $\left(\mathrm{I}^{2}=94.4 \%\right)$ and Egger's regression test ruled out publication bias $(\mathrm{p}=0.82)$. The heterogeneity continued to be high when only studies with more than 20 patients (6 studies ${ }^{29} 28313336$ $\mathrm{I}^{2}=99.9 \% ; \mathrm{p}=0.001$ ). (Supplementary Figure 3). 
Funnel plots and Egger's Regression test for $\mathrm{PaO}_{2} / \mathrm{FiO}_{2}, \mathrm{PaO}_{2}$ and $\mathrm{SpO}_{2}$ are presented in Supplementary Figure 4.

\section{Secondary Outcomes:}

Intubation after a trial of PP was reported in 14 studies. $^{2}{ }^{1026-37}$ A total of 90 patients out of $426(21.1 \%)$ were intubated following a trial of PP. The studies demonstrated moderate heterogeneity $\left(\mathrm{I}^{2}=74.3 \%\right)$. The Forest plot and Funnel plot for intubation is presented in Figure 4. However, there was no publication bias (Egger's regression test $\mathrm{p}=0.52$ ).

Mortality in patients who underwent awake PP was reported in 13 studies. ${ }^{9}{ }^{10}{ }^{26-29}{ }^{31-37}$ Overall, 101 patients out of 390 (25.9\%) died. The studies demonstrated high heterogeneity $\left(\mathrm{I}^{2}=83.6 \%\right)$, however, there was minimal publication bias (Egger's regression test $\mathrm{p}=0.51$ ). The Forest plot and Funnel plot for intubation is presented in Figure 4.

Funnel plots and Egger's Regression test for intubation and mortality are illustrated in Supplementary Figure 5.

There were no reported life-threatening or major adverse events following PP. Only reported minor events included pain in the back, sternum or scrotum; general discomfort, dyspnoea and coughing and confusion in a small number of patients. ${ }^{263637}$

Oxygenation outcomes were analysed based on the mean pre-PP $\mathrm{PaO}_{2} / \mathrm{FiO}_{2} \leq 150$ (5 studies ${ }^{1028} 293337$ ) or $>150$ (6 studies $\begin{array}{lllll}2 & 27 & 30 & 32 & 35\end{array}$ ). Patients with a Pre-PP $\mathrm{PaO}_{2} / \mathrm{FiO}_{2} \leq 150$ had statistically significant oxygenation improvements post-PP ( $\mathrm{MD}=37$ [95\%-CI 17.1-56.9] vs. $\mathrm{MD}=40.5$ [95\%-CI -3.5-84.6]) when compared with those with a pre- $\mathrm{PP} \mathrm{PaO}_{2} / \mathrm{FiO}_{2}>150$ (Figure 5).

Eight studies ${ }^{2}{ }^{26-36}$ reported changes in RR upon PP. There was a significant reduction in RR post-PP (MD -2.9, 95\%-CI -5.4 to -0.4). High heterogenicity was observed $\left(\mathrm{I}^{2}=93.4 \%\right)$ (Supplementary Figure 6) which persisted despite exclusion of smaller studies $\left(\mathrm{I}^{2}=77.5 \%\right.$; $\left.\mathrm{p}=0.01\right)$.

About a quarter of patients (111/410) received PP in ICU while others (309/410) received it in HDU, general wards and respiratory unit areas of the hospital. Physiological and clinically relevant outcomes were compared between these two locations (Supplementary Figure 7). In studies that reported on $\mathrm{PaO}_{2} / \mathrm{FiO}_{2}$ ratio, there was relatively higher improvement in $\mathrm{PaO}_{2} / \mathrm{FiO}_{2}$ in ICU patients (ICU $\mathrm{MD}=43.5$ [95\%-CI 11.5-75.4; $\mathrm{p}=0.001])$ when compared with non-ICU patients (MD=40.8 [95\%-CI 20.6-60.9; $\mathrm{p}=0.001]) . \mathrm{PaO}_{2}$ improvement was statistically significant in ICU patients ( $\mathrm{MD}=23.8$ 95\%-CI 14.7-32.9), 
whereas the improvement was insignificant in non-ICU group (MD=49.4 95\%-CI -6.6-105.5). The overall improvement in $\mathrm{SpO}_{2}$ was $6.0 \%$ (95\%-CI 3.8-8.2), however the difference was statistically insignificant between ICU (MD=5.82 95\%-CI 2.46-9.16) and non-ICU (MD=6.54 95\%-CI 4.31-8.76) location for PP $(\mathrm{p}=0.73)$. Of the 90 patients who were subsequently intubated; 64 patients $(71.1 \%)$ received PP outside ICU (28.9\% [26/90] in ICU vs. 71.1\% [64/90]; p=0.002). Mortality data were available in 12 studies $^{9} 10$ 26-29 31-34 3637 where patients had PP either in ICU or outside ICU. A total of 23/255 patients died (12.6\% [14/111] in ICU vs. 9.6\%. [9/94] in Non-ICU areas; $p=0.49)$.

\section{DISCUSSION}

This systematic review examined the effect of PP of non-intubated patients on oxygenation parameters in a heterogenous group of adult patients with COVID-19-related hypoxaemic respiratory failure. There was a significant improvement in oxygenation parameters $\left(\mathrm{PaO}_{2} / \mathrm{FiO}_{2}, \mathrm{PaO}_{2}\right.$ and $\left.\mathrm{SpO}_{2}\right)$ and respiratory rate upon PP. An improvement in these parameters was consistent, although there was significant variability in both treatment dose and effect. However, due to the inconsistency of reporting physiologic outcomes, it was unclear which of these parameters may provide the best clinical guidance in terms of both patient selection for PP and evaluation of treatment response. Other relevant data for example, relative changes in patients respiratory drive, dyspnoea scores and patient comfort were not consistently available. Given these limitations, the population that clearly stands to benefit from PP could not be clearly defined.

Although all patients demonstrated improved oxygenation, the patients with $\mathrm{PaO}_{2} / \mathrm{FiO}_{2}$ ratio of $\leq 150$ demonstrated a greater improvement. The reasons may possibly be that patients with more severe hypoxaemia had a greater degree of pulmonary vascular dysregulation and ventilation: those with perfusion mismatch to start with and benefited more with PP. However, such an interpretation is speculative and not much inference can be drawn from these data as an improved oxygenation with PP depends on several factors such as timing, duration, underlying pathophysiology and other respiratory supports used. For example, the duration of and frequency of prone ventilation were quite variable with some studies reporting a combination of lateral positioning and PP. Such variability is a concern when it comes to feasibility and generalisability of PP outside of centres that have some experience in PP of awake patients.

In addition, there was significant heterogeneity in oxygen therapies provided prior to and during PP. For example, $69 \%$ of the patients were receiving NIV and $12.6 \%$ were receiving oxygen via nasal cannula. These two populations can be drastically different and may represent different stages of disease evolution. This is likely to have a significant bearing on adjunctive use of PP as essentially the outcomes depend on the success of combinations of these therapies. It should be noted that ARDS studies only tested PP in intubated patients enrolled patients with a $\mathrm{PaO}_{2} / \mathrm{FiO}_{2} \leq 150$ to bring in some homogeneity in an otherwise heterogenous population of ARDS. In a recent network meta-analysis of trials of adult patients with acute 
hypoxaemic respiratory failure, ${ }^{38}$ treatment with non-invasive oxygenation strategies compared with standard oxygen therapy was associated with lower risk of death. Most of the included studies predated the RECOVERY trial ${ }^{39}$ and there was no consistent reporting on use of steroids or other disease modifying therapies limiting interpretation of the findings of the review.

Although there were no reported major adverse events following PP, not all included studies reported adverse events. Therefore, safety and efficacy of this intervention can only be tested in a well-designed randomised controlled trial and they are ongoing. ${ }^{40} 41$ Placing critically ill, hypoxaemic, non-intubated patients in a prone position outside closely monitored units without ability to administer invasive mechanical ventilation when required may lead to poor outcomes. PP should be carefully undertaken in systems where this can be safely provided pending further evidence. Equally, PP may be considered as a useful adjunct in patients who are considered not suitable candidates for invasive mechanical ventilation while making sure their comfort and dignity is also prioritised.

In a selected group of patients who received PP, the incidence of intubation and mortality was relatively lower in comparison with a recent systematic review and meta-analysis on associations of non-invasive oxygenation strategies and all-cause mortality in COVID-19, which reported rates of $40 \%$ and $30 \%$ respectively. ${ }^{38}$ In the absence of appropriate controls who did not receive PP for comparison, it is unclear whether these physiologic improvements resulted in reduced need for intubation or mortality. A noticeable difference was observed between the patients who had PP in ICU compared with other areas of the hospital both in terms of improvement in oxygenation and intubation rates. The oxygenation improvements were more marked in patients who underwent PP in ICU and there were corresponding lower intubation rates in ICU patients. However, a recent cohort study did not show any reduction in intubation rates or 28-day mortality in COVID-19 patients who received awake PP as an adjunctive therapy to $\mathrm{HFNO}^{42}$ It is possible that a selected patient population of non-intubated patients with COVID-19-related respiratory failure may benefit from PP. However, data available for this review was not of sufficient quality to identify the precise population that may benefit. Based on this review, PP appears feasible and safe in patients who are hypoxaemic and when undertaken in appropriately monitored environments.

Our study has some important limitations. This review was based on data from single arm observational case series and cohort studies that had no comparator groups. Consequently, heterogeneity and all the antecedent biases associated with patient selection and reporting was expected. The heterogeneity persisted despite sensitivity analyses were performed based on sample size. Given the inconsistent reporting of oxygenation parameters, we had to derive some of the variables from other reported variables and where possible requested missing data from the corresponding authors of the included studies. Despite this, we still had missing variables in some of the included studies. This calls for a validated 
system to report changes in physiologic parameters in future studies that test respiratory supports in nonintubated patients. Healthcare worker infection risks and rates while assisting/facilitating PP were not reported in any of the studies. In addition, strong conclusions cannot be reached due to several factors: first, the absence of tested, established triggers and a standardised process for initiating PP in nonintubated COVID-19 patients; second, the significant heterogeneity in the patient populations included and lack of granular data on co-interventions used (NIV, HFNC, Steroids, Antiviral therapies etc.); third, an absence of standardised intubation criteria; and, fourth, that the intervention was provided in some instances under pandemic stressors that affected resource availability.

\section{CONCLUSION}

There was a variable but significant improvement in oxygenation parameters with PP in non-intubated, hypoxic adult patients with COVID-19-related hypoxaemia. This review observed a lack of a standardised process for PP in non-intubated patients. Significant heterogeneity, inconsistent reporting, poor data quality and potential biases in data may affect the analysis. Absence of standardised intubation criteria and the provision of the intervention under pandemic stressors further limit interpretation. Well designed, randomised control studies testing the efficacy of PP in non-intubated COVID-19 patients are needed prior to widespread adoption of this practice.

\section{ACKNOWLEDGMENT}

We thank authors of all the studies for providing us with the data needed for our systematic review and meta-analysis. We are also grateful to Dr. Ata Mahmoodpoor, Dr. Xu Q, Dr. Tom Lawton, Dr. Caputo for responding to our request for additional information used in this study. Prof Shekar acknowledges the Metro North Hospital and Health Service for research support.

\section{LEGENDS}

Table 1: 15 studies included in this systematic review and meta-analysis.

Figure 1: PRISMA (Preferred reporting items for systematic reviews and meta-analyses) flowchart of study inclusions and exclusions.

Figure 2: Graphical representation of mean improvements in physiological parameters post-PP

Figure 3: Primary Outcome demonstrating the physiological parameters post-PP.

Figure 4: Secondary outcomes: Forest plots for rates of intubation and mortality in patients who underwent PP.

Figure 5: Secondary Analysis based on $\mathrm{P} / \mathrm{F}$ ratio demonstrate that $\mathrm{PaO}_{2} / \mathrm{FiO}_{2} \leq 150$ pre-PP had statistically significant improvements when compared with $\mathrm{PaO}_{2} / \mathrm{FiO}_{2}>150$. 
Supplementary Figure 1: Sensitivity analysis to minimise heterogeneity for $\mathrm{PaO}_{2} / \mathrm{FiO}_{2}$ based on study sample size.

Supplementary Figure 2: Sensitivity analysis to minimise heterogeneity for $\mathrm{PaO}_{2}$ based on study sample size.

Supplementary Figure 3: Sensitivity analysis to minimise heterogeneity for $\mathrm{SpO}_{2}$ based on study sample size.

Supplementary Figure 4: Funnel plots and Egger's regression tests for $\mathrm{PaO}_{2} / \mathrm{FiO}_{2}, \mathrm{PaO}_{2}$ and $\mathrm{SpO}_{2}$.

Supplementary Figure 5: Secondary Outcomes: Funnel plots for rates of intubation and mortality in patients who underwent PP.

Supplementary Figure 6: Secondary Outcomes: Reduction in respiratory rates who underwent PP. Graphical representation of mean of mean difference pre and post-PP along with Forest plot, Funnel plot, Egger's regression and sensitivity analysis for study sample size $>20$.

Supplementary Figure 7: Secondary Outcomes: Analysis of physiological parameters (P/F ratio and $\mathrm{SpO}_{2}$ ) based on patients' location (ICU vs non-ICU areas) when PP was attempted.

Supplementary Table 1: Search terms and search engines used for the systematic review

Supplementary Table 2: Quality Assessment and risk of bias in individual studies evaluated using NOS and JBI Critical appraisal chest list.

Supplementary Table 3: Equation used for conversion of $\mathrm{PaO} 2$ to $\mathrm{SPO} 2$ and deriving SPO2 from PaO2.

Supplementary Table 4: Equation used to calculate mean and standard deviation from median and Inter quartile range.

Supplementary Table 5: Diversity in oxygen delivery modes and variation in $\mathrm{FiO} 2$ in the study participants. 
Table 1 Studies included in the systematic review and meta-analysis.

\begin{tabular}{|c|c|c|c|c|c|c|c|c|c|c|c|c|}
\hline \multirow[t]{2}{*}{$\begin{array}{l}\text { Author, } \\
\text { reference }\end{array}$} & \multirow[t]{2}{*}{ n* } & \multirow[t]{2}{*}{ Settings } & \multirow[t]{2}{*}{$\begin{array}{l}\text { Patient } \\
\text { location of } \\
\text { PP }\end{array}$} & \multirow{2}{*}{$\begin{array}{l}\text { Supplemental } \\
\text { oxygen and } \\
\text { non-invasive } \\
\text { respiratory } \\
\text { support }\end{array}$} & \multirow{2}{*}{$\begin{array}{l}\text { Number of } \\
\text { episodes, } \\
\text { And } \\
\text { duration of } \\
\text { PP (hours) }\end{array}$} & \multirow{2}{*}{$\begin{array}{l}\text { Mean } \\
\text { duration of } \\
\text { PP when } \\
\text { respiratory } \\
\text { parameters } \\
\text { were assessed } \\
\text { (minutes) }\end{array}$} & \multicolumn{3}{|c|}{$\begin{array}{l}\text { Respiratory physiology } \\
\text { parameters reported } \\
\text { pre- and post PP }\end{array}$} & \multicolumn{3}{|c|}{ Other outcome parameters reported } \\
\hline & & & & & & & $\begin{array}{l}\mathrm{P} / \mathrm{F} \\
\text { ratio }\end{array}$ & $\mathbf{R R}$ & $\mathrm{SpO}_{2}$ & $\begin{array}{l}\text { Hospital } \\
\text { mortality }\end{array}$ & $\begin{array}{l}\text { Patients } \\
\text { requiring } \\
\text { intubation }\end{array}$ & $\begin{array}{l}\text { Hospital } \\
\text { length of } \\
\text { stay }\end{array}$ \\
\hline Caputo et al ${ }^{2}$ & 50 & $\begin{array}{l}\text { Single Centre, } \\
\text { NY, USA. }\end{array}$ & ED & $\mathrm{NRB}$ and $\mathrm{NC}$ & $1,(\mathrm{NR})$ & 5 & $\mathrm{D}$ & NR & + & NR & + & NR \\
\hline Coppo et al ${ }^{26}$ & 46 & $\begin{array}{l}\text { Single Centre, } \\
\text { Monza, Italy }\end{array}$ & $\begin{array}{l}\text { ED, } \\
\text { Respiratory } \\
\text { HDU }\end{array}$ & $\begin{array}{l}\text { NIV, VM and } \\
\text { NRB }\end{array}$ & $1-3,(3.5 \mathrm{hrs})$ & 10 & + & + & + & + & + & NR \\
\hline Damarla et al ${ }^{27}$ & 10 & $\begin{array}{l}\text { Single Centre, } \\
\text { Baltimore, USA }\end{array}$ & $\mathrm{ICU}^{\wedge}$ & HFNC and NC & $\begin{array}{l}\text { Multiple (2 } \\
\text { hrs) }\end{array}$ & 60 & $\mathrm{D}$ & + & + & 0 & + & NR \\
\hline Despres et al ${ }^{10}$ & 6 & $\begin{array}{l}\text { Single Centre, } \\
\text { Besancon, France }\end{array}$ & ICU & HFNC or VM & $\begin{array}{l}\text { Multiple (1- } \\
7 \mathrm{hrs)}\end{array}$ & 180 & + & NR & $\mathrm{D}$ & NR & + & NR \\
\hline Dong et al ${ }^{37}$ & 25 & $\begin{array}{l}\text { Single Centre, } \\
\text { Wuhan, China }\end{array}$ & ICU & $\begin{array}{l}\text { HFNC, VM, } \\
\text { NC and NIV }\end{array}$ & Daily (4.9) & 294 & + & + & NR & 0 & 0 & NR \\
\hline Elharrar et al ${ }^{36}$ & 24 & $\begin{array}{l}\text { Single Centre, } \\
\text { France }\end{array}$ & NR & $\mathrm{NC}$ and $\mathrm{HFNC}$ & $\begin{array}{l}<1 \mathrm{~h}, 1-3 \mathrm{hrs}, \\
>3 \mathrm{hrs}\end{array}$ & 90 & $\mathrm{D}$ & + & $\mathrm{D}$ & NR & + & NR \\
\hline $\begin{array}{l}\text { Golestani- } \\
\text { Eraghi et al }\end{array}$ & 10 & $\begin{array}{l}\text { Single Centre, } \\
\text { Teheran, Iran }\end{array}$ & ICU & NIV & $\begin{array}{l}\text { NR/multiple } \\
(14 \mathrm{hr})\end{array}$ & NR & + & NR & $\mathrm{D}$ & + & + & NR \\
\hline Lawton et al ${ }^{28}$ & 165 & $\begin{array}{l}\text { Single Centre } \\
\text { Bradford, UK }\end{array}$ & Ward, ED & NIV & 2 times/day & 30 & + & + & + & + & + & NR \\
\hline$\underset{34}{\text { Moghadam et al }}$ & 10 & $\begin{array}{l}\text { Single Centre, } \\
\text { Qom, Iran }\end{array}$ & ICU & NR & NR & NR & NR & + & + & NR & 0 & + \\
\hline Retucci et al ${ }^{33}$ & 26 & $\begin{array}{l}\text { Single Centre, } \\
\text { Milan, Italy }\end{array}$ & $\begin{array}{l}\text { Respiratory } \\
\text { HDU }\end{array}$ & NIV & 29 (1 hr) & 60 & + & + & + & + & + & NR \\
\hline Sartini et al ${ }^{32}$ & 15 & $\begin{array}{l}\text { Single Centre, } \\
\text { Milan, Italy }\end{array}$ & $\begin{array}{l}\text { ICU/medical } \\
\text { ward }\end{array}$ & NIV & $1-3$ (1-6hrs) & 60 & + & + & + & + & + & + \\
\hline Thompson et al & 29 & $\begin{array}{l}\text { Single Centre, } \\
\text { NY, USA }\end{array}$ & $\mathrm{HDU}$ & $\mathrm{NRB}$ and NC & $1 \mathrm{hr}$ & 60 & + & NR & + & + & + & NR \\
\hline Tu et al ${ }^{30}$ & 9 & $\begin{array}{l}\text { Single Centre, } \\
\text { Shanghai, China }\end{array}$ & ICU & $\begin{array}{l}\text { HFNC and } \\
\text { NIV }\end{array}$ & $\begin{array}{l}3-8(1-4 \\
\mathrm{hrs})\end{array}$ & 120 & + & NR & + & + & $+/-$ & NR \\
\hline Xu et al ${ }^{29}$ & 10 & $\begin{array}{l}\text { Single Centre, } \\
\text { Anhui, China. }\end{array}$ & ICU & HFNC & $3(16 \square \mathrm{hrs})$ & 300 & + & NR & + & 0 & 0 & + \\
\hline
\end{tabular}




\begin{tabular}{|c|c|c|c|c|c|c|c|c|c|c|c|c|}
\hline Zang et al ${ }^{9}$ & 23 & $\begin{array}{l}\text { Single Centre, } \\
\text { Beijing, China }\end{array}$ & ICU & HFNC & $\begin{array}{l}13.43(8.04) \\
\text { hrs }\end{array}$ & 30 & D & + & + & + & + & NR \\
\hline \multicolumn{13}{|c|}{$\begin{array}{l}\mathrm{n}^{*} \text { - number of awake prone positioned patients in the study } \\
\wedge \text { PP in } 1 \text { of the } 10 \text { patients happened in medical ward following ICU consultation and supervision } \\
\text { NRB - Non-rebreather mask, hrs - hours; NC - Nasal cannula, HFNC - High-flow nasal cannula, VM - Venturi Mask / Hudson Mask, NIV - Non-invasive ventilation, ED - } \\
\text { emergency department, ICU - intensive care unit, HDU - high dependency unit, PP - prone positioning, D - the parameter was derived from other reported values, NR - the } \\
\text { parameter was not reported in the study, + - the parameter was reported, } 0 \text { - no events. }\end{array}$} \\
\hline
\end{tabular}

emergency department, ICU - intensive care unit, HDU - high dependency unit, $\mathrm{PP}$ - prone positioning, D - the parameter was derived from other reported values, NR - the

parameter was not reported in the study, + - the parameter was reported, 0 - no events. 
Supplementary Table 1: Search terms and search engines used for the systematic review

\begin{tabular}{|c|c|}
\hline Pubmed: & $\begin{array}{l}\text { "severe acute respiratory syndrome coronavirus 2"[Supplementary Concept] OR } \\
\text { "COVID-19"[Supplementary Concept] OR } \\
\text { "Coronavirus Infections"[MeSH Terms] OR COVID-19[Title/Abstract] OR } \\
\text { "sars cov-2" [Title/Abstract] OR MERS-CoV[Title/Abstract] OR } \\
\text { hCov*[Title/Abstract] OR "corona virus disease"[Title/Abstract] OR } \\
\text { ((coronavirus*[Title/Abstract] OR ncov[Title/Abstract] OR sars- } \\
\text { cov[Title/Abstract]) AND (2019[Title/Abstract] OR 19[Title/Abstract] } \\
\text { OR Wuhan[Title/Abstract] OR human[Title/Abstract] OR } \\
\text { MERS[Title/Abstract])) } \\
\text { AND } \\
\text { ("Prone position”[Mesh]) OR (“prone position*”[Title/Abstract] OR } \\
\text { proning[Title/Abstract]) }\end{array}$ \\
\hline Scopus: & $\begin{array}{l}\text { TITLE-ABS-KEY((COVID-19 OR "sars cov-2" OR MERS-CoV OR hCov* OR } \\
\text { "corona virus disease" OR ((coronavirus* OR ncov OR sars-cov) W/3 (2019 OR } \\
19 \text { OR Wuhan OR human OR MERS))) AND ("prone position*" OR proning)) }\end{array}$ \\
\hline Embase: & $\begin{array}{l}\text { ('covid 19'/exp OR 'coronavirus disease 2019'/exp OR 'coronavirus infection'/exp } \\
\text { OR 'severe acute respiratory syndrome coronavirus 2'/exp OR 'covid 19':ab,ti OR } \\
\text { 'sars cov-2':ab,ti OR 'mers cov':ab,ti OR hcov*:ab,ti OR 'corona virus } \\
\text { disease':ab,ti OR (((coronavirus* OR ncov OR 'sars cov') NEAR/3 (2019 OR } 19 \\
\text { OR wuhan OR human OR mers)):ab,ti)) AND ('prone position'/exp OR 'prone } \\
\text { position*':ab,ti OR proning:ab,ti) }\end{array}$ \\
\hline $\begin{array}{l}\text { Living systematic } \\
\text { review: }\end{array}$ & $\begin{array}{l}\text { "severe acute respiratory syndrome coronavirus 2"[Supplementary Concept] OR } \\
\text { "COVID-19"[Supplementary Concept] OR } \\
\text { "Coronavirus Infections"[MeSH Terms] OR COVID-19[Title/Abstract] OR } \\
\text { "sars cov-2" [Title/Abstract] OR MERS-CoV[Title/Abstract] OR } \\
\text { hCov*[Title/Abstract] OR "corona virus disease"[Title/Abstract] OR } \\
\text { ((coronavirus*[Title/Abstract] OR ncov[Title/Abstract] OR sars- } \\
\text { cov[Title/Abstract]) AND (2019[Title/Abstract] OR 19[Title/Abstract] } \\
\text { OR Wuhan[Title/Abstract] OR human[Title/Abstract] OR } \\
\text { MERS[Title/Abstract])) } \\
\text { AND } \\
\text { (“Prone position”[Mesh]) OR (“prone position*”[Title/Abstract] OR } \\
\text { proning[Title/Abstract]) }\end{array}$ \\
\hline
\end{tabular}


Supplementary Table 2: Quality Assessment and risk of bias in individual studies evaluated using Newcastle Ottawa Scale and Joanna Briggs Institute Critical appraisal checklist.

\begin{tabular}{|c|c|c|c|c|c|c|c|c|c|c|c|}
\hline \multirow{3}{*}{ Author } & \multicolumn{8}{|c|}{ Newcastle Ottawa Scale (NOS) } & \multirow{3}{*}{$\begin{array}{c}\text { NOS } \\
\text { Grade }\end{array}$} & \multirow{2}{*}{\multicolumn{2}{|c|}{$\begin{array}{c}\text { Joanna Briggs } \\
\text { Institute } \\
\text { Checklist }\end{array}$}} \\
\hline & \multicolumn{2}{|c|}{ Selection } & \multicolumn{2}{|c|}{$\begin{array}{l}\text { Comparability/ } \\
\text { Confounder }\end{array}$} & \multicolumn{2}{|c|}{ Outcome } & \multicolumn{2}{|c|}{ Total } & & & \\
\hline & MR & ZL/AS & MR & ZL/AS & MR & $\mathbf{Z L / A S}$ & MR & ZL/AS & & MR & $\mathbf{Z L}$ \\
\hline${\text { Caputo et } \mathrm{al}^{2}}^{2}$ & $* * * *$ & $* * * *$ & $*$ & $*$ & $* * *$ & $* * *$ & 8 & 8 & Good & NA & NA \\
\hline Coppo et al ${ }^{26}$ & $* * * *$ & $* * * *$ & $*$ & $*$ & $* * *$ & $* * *$ & 8 & 8 & Good & NA & NA \\
\hline Damarla et al $^{27}$ & NA & NA & NA & NA & NA & NA & NA & NA & NA & 8 & 8 \\
\hline Despres et al ${ }^{10}$ & NA & NA & NA & NA & NA & NA & NA & NA & NA & 8 & 8 \\
\hline${\text { Dong et } \mathrm{al}^{37}}^{37}$ & $* * *$ & $* * *$ & 0 & 0 & $* * *$ & $* * *$ & 6 & 6 & Poor & NA & NA \\
\hline Elharrar et al ${ }^{36}$ & $* * * *$ & $* * * *$ & 0 & 0 & $* * *$ & $* * *$ & 7 & 7 & Fair & NA & NA \\
\hline Golestani-Eraghi et al ${ }^{35}$ & $* * *$ & $* * *$ & 0 & 0 & $* * *$ & $* * *$ & 6 & 6 & Poor & NA & NA \\
\hline Lawton et al ${ }^{28}$ & $* * * *$ & $* * * *$ & 0 & 0 & $* *$ & $* *$ & 6 & 6 & Poor & NA & NA \\
\hline Moghadam et al ${ }^{34}$ & NA & NA & NA & NA & NA & NA & NA & NA & NA & 7 & 8 \\
\hline Retucci et al $^{33}$ & $* * *$ & $* * *$ & 0 & 0 & $* *$ & $* *$ & 5 & 5 & Poor & NA & NA \\
\hline Sartini et al ${ }^{32}$ & $* * * *$ & $* * * *$ & 0 & 0 & $* *$ & $* *$ & 6 & 6 & Poor & NA & $\mathrm{NA}$ \\
\hline Thompson et al ${ }^{31}$ & $* * *$ & $* * *$ & 0 & 0 & $* * *$ & $* * *$ & 6 & 6 & Poor & NA & NA \\
\hline Tu et al ${ }^{30}$ & NA & NA & NA & NA & NA & NA & NA & NA & $\mathrm{NA}$ & 8 & 8 \\
\hline $\mathrm{Xu}$ et al ${ }^{29}$ & $* * * *$ & $* * * *$ & 0 & 0 & $* * *$ & $* * *$ & 7 & 7 & Fair & NA & NA \\
\hline Zang et al ${ }^{9}$ & $* * * *$ & $* * * *$ & $* *$ & $* *$ & $* *$ & $* * *$ & 8 & 9 & Good & NA & NA \\
\hline
\end{tabular}


medRxiv preprint doi: https://doi.org/10.1101/2020.10.12.20211748; this version posted October 14, 2020. The copyright holder for this preprint (which was not certified by peer review) is the author/funder, who has granted medRxiv a license to display the preprint in perpetuity.

It is made available under a CC-BY-NC-ND 4.0 International license .

Supplementary Table 3: Equation used for conversion of $\mathrm{PaO}_{2}$ to $\mathrm{SPO}_{2}$ and deriving $\mathrm{SPO}_{2}$ from $\mathrm{PaO}_{2}$.

\begin{tabular}{|c|c|c|}
\hline $\mathrm{SpO}_{2}$ (On monitor) & Calculation for $\mathrm{PaO}_{2}$ & Resultant $\mathrm{PaO}_{2}$ range \\
\hline $100 \%-90 \%$ & $\begin{array}{l}\text { Decrease } \mathrm{PaO}_{2} \text { by } 4 \mathrm{mmHg} \text { for every single } \\
\text { percent reduction in } \mathrm{SpO} 2\end{array}$ & $100-60 \mathrm{mmHg}$ \\
\hline $90 \%-80 \%$ & $\begin{array}{l}\text { Decrease } \mathrm{PaO}_{2} \text { by } 1.5 \mathrm{mmHg} \text { for every } \\
\text { single percent reduction in } \mathrm{SpO} 2\end{array}$ & $60-45 \mathrm{mmHg}$ \\
\hline$<80 \%$ & Divide $\mathrm{SpO} 2$ by ${ }_{2}$ to reach to $\mathrm{PaO}_{2}$ level & $40 \mathrm{mmHg}$ and downward \\
\hline
\end{tabular}

Supplementary Table 4: Equation used to calculate mean and standard deviation from median and Inter quartile range.

\begin{tabular}{|c|c|}
\hline Mean / Standard Deviation derivations & Equation \\
\hline Equation used to derive mean from median and IQR & $\mathrm{X} \square \approx\left(\mathrm{q}_{1}+\mathrm{m}+\mathrm{q}_{3}\right) / 3$ \\
\hline Equation used to derive standard deviation from median and IQR & $\mathrm{S} \approx\left(\mathrm{q}_{3}-\mathrm{q}_{1}\right) / 1.35$ \\
\hline \multicolumn{2}{|c|}{$\begin{array}{l}\mathrm{q}_{1}=\text { the first quartile; } \mathrm{q}_{3}=\text { the third quartile; } \mathrm{m}=\text { the median; } \mathrm{X} \square=\text { the mean; } \mathrm{S}=\text { the Standard } \\
\text { deviation, IQR }- \text { interquartile range. } \\
\text { Adapted from "Estimating the sample mean and standard deviation from the sample size, median, range } \\
\text { and/or interquartile range." By Wan X 2014, BMC Med Res Methodology } 14: 135 .^{22}\end{array}$} \\
\hline
\end{tabular}

Supplementary Table 5: Diversity in oxygen delivery modes and variation in FiO2 in the study participants.

\begin{tabular}{|l|l|}
\hline Oxygen delivery mode & Reported patients $(\mathbf{N}=\mathbf{3 5 0})$ \\
\hline NIV & $241 / 350(68.9 \%)$ \\
\hline HFNC & $17 / 350(4.9 \%)$ \\
\hline Hudson Mask & $48 / 350(13.7 \%)$ \\
\hline Nasal Cannula & $44 / 350(12.6 \%)$ \\
Fraction of inhaled Oxygen $\left(\mathbf{F i O}_{2}\right)$ & Reported patients $(\mathbf{N}=\mathbf{2 7 7})$ \\
\hline$>0.70$ & $56 / 277(20.2 \%)$ \\
\hline $0.70-0.50$ & $46 / 277(16.6 \%)$ \\
\hline$<0.50$ & $175 / 277(63.2 \%)$ \\
\hline NIV = Non-Invasive Ventilation, HFNP= High Flow Nasal Cannula \\
\hline
\end{tabular}




\section{REFERENCES:}

1. Wu C, Chen X, Cai Y, et al. Risk Factors Associated With Acute Respiratory Distress Syndrome and Death in Patients With Coronavirus Disease 2019 Pneumonia in Wuhan, China. JAMA Intern Med 2020 doi: 10.1001/jamainternmed.2020.0994 [published Online First: 2020/03/14]

2. Caputo ND, Strayer RJ, Levitan R. Early Self-Proning in Awake, Non-intubated Patients in the Emergency Department: A Single ED's Experience During the COVID-19 Pandemic. Acad Emerg Med 2020;27(5):375-78. doi: 10.1111/acem.13994 [published Online First: 2020/04/23]

3. Phua J, Weng L, Ling L, et al. Intensive care management of coronavirus disease 2019 (COVID-19): challenges and recommendations. Lancet Respir Med 2020 doi: 10.1016/S2213-2600(20)30161-2 [published Online First: 2020/04/10]

4. Abate SM, Ahmed Ali S, Mantfardo B, et al. Rate of Intensive Care Unit admission and outcomes among patients with coronavirus: A systematic review and Meta-analysis. PLoS One 2020;15(7):e0235653. doi: 10.1371/journal.pone.0235653 [published Online First: 2020/07/11]

5. Sarma A, Calfee CS. Prone Positioning in Awake, Nonintubated Patients With COVID-19: Necessity Is the Mother of Invention. JAMA Intern Med 2020 doi: 10.1001/jamainternmed.2020.3027 [published Online First: 2020/06/26]

6. Bloomfield R, Noble DW, Sudlow A. Prone position for acute respiratory failure in adults. Cochrane Database Syst Rev 2015(11):CD008095. doi: 10.1002/14651858.CD008095.pub2 [published Online First: 2015/11/13]

7. Scaravilli V, Grasselli G, Castagna L, et al. Prone positioning improves oxygenation in spontaneously breathing nonintubated patients with hypoxemic acute respiratory failure: A retrospective study. $J$ Crit Care 2015;30(6):1390-4. doi: 10.1016/j.jcrc.2015.07.008 [published Online First: 2015/08/15]

8. Munshi L, Fralick M, Fan E. Prone positioning in non-intubated patients with COVID-19: raising the bar. Lancet Respir Med 2020;8(8):744-45. doi: 10.1016/S2213-2600(20)30269-1 [published Online First: 2020/06/23]

9. Zang X, Wang Q, Zhou H, et al. Efficacy of early prone position for COVID-19 patients with severe hypoxia: a single-center prospective cohort study. Intensive Care Med 2020 doi: 10.1007/s00134020-06182-4 [published Online First: 2020/07/24]

10. Despres C, Brunin Y, Berthier F, et al. Prone positioning combined with high-flow nasal or conventional oxygen therapy in severe Covid-19 patients. Crit Care 2020;24(1):256. doi: 10.1186/s13054-020-03001-6 [published Online First: 2020/05/28]

11. Patel BK, Kress JP, Hall JB. Alternatives to Invasive Ventilation in the COVID-19 Pandemic. JAMA 2020 doi: 10.1001/jama.2020.9611 [published Online First: 2020/06/05]

12. Protti A, Chiumello D, Cressoni M, et al. Relationship between gas exchange response to prone position and lung recruitability during acute respiratory failure. Intensive Care Med 2009;35(6):1011-7. doi: 10.1007/s00134-009-1411-x [published Online First: 2009/02/04]

13. Vieillard-Baron A, Rabiller A, Chergui K, et al. Prone position improves mechanics and alveolar ventilation in acute respiratory distress syndrome. Intensive Care Medicine 2005;31(2):220-26. doi: 10.1007/s00134-004-2478-z

14. Gattinoni L, Coppola S, Cressoni M, et al. COVID-19 Does Not Lead to a "Typical" Acute Respiratory Distress Syndrome. Am J Respir Crit Care Med 2020;201(10):1299-300. doi: 10.1164/rccm.202003-0817LE [published Online First: 2020/04/02]

15. Moher D, Liberati A, Tetzlaff J, et al. Preferred reporting items for systematic reviews and metaanalyses: the PRISMA statement. BMJ 2009;339:b2535. doi: 10.1136/bmj.b2535 [published Online First: 2009/07/23]

16. Counotte M IH, Ipekci M, Low N. COAP Living Evidence on COVID-19, 2020.

17. Counotte MJ, Egli-Gany D, Riesen M, et al. Zika virus infection as a cause of congenital brain abnormalities and Guillain-Barre syndrome: From systematic review to living systematic review. F1000Res 2018;7:196. doi: 10.12688/f1000research.13704.1 [published Online First: 2019/01/12]

18. Wynants L, Van Calster B, Collins GS, et al. Prediction models for diagnosis and prognosis of covid19 infection: systematic review and critical appraisal. BMJ 2020;369:m1328. doi: 10.1136/bmj.m1328 [published Online First: 2020/04/09] 
19. GA Wells BS, D O'Connell, J Peterson, V Welch, M Losos, P Tugwell. The Newcastle-Ottawa Scale (NOS) for assessing the quality of nonrandomised studies in meta-analyses Ottawa2013 [Available from: http://www.ohri.ca/programs/clinical_epidemiology/oxford.asp accessed September 4th 2020.

20. Munn Z BT, Moola S, Tufanaru C, Stern C, McArthur A, Stephenson M, Aromataris, E. Methodological quality of case series studies, JBI Evidence Synthesis. doi: 10.11124/JBISRIRD-19-00099

21. Madan A. Correlation between the levels of SpO2and PaO2. Lung India 2017;34(3):307-08. doi: 10.4103/lungindia.lungindia_106_17 [published Online First: 2017/05/06]

22. Wan X, Wang W, Liu J, et al. Estimating the sample mean and standard deviation from the sample size, median, range and/or interquartile range. BMC Med Res Methodol 2014;14:135. doi: 10.1186/1471-2288-14-135 [published Online First: 2014/12/20]

23. Nyaga VN, Arbyn M, Aerts M. Metaprop: a Stata command to perform meta-analysis of binomial data. Arch Public Health 2014;72(1):39. doi: 10.1186/2049-3258-72-39 [published Online First: 2014/01/01]

24. Higgins JP, Thompson SG, Deeks JJ, et al. Measuring inconsistency in meta-analyses. BMJ 2003;327(7414):557-60. doi: 10.1136/bmj.327.7414.557 [published Online First: 2003/09/06]

25. Egger M, Davey Smith G, Schneider M, et al. Bias in meta-analysis detected by a simple, graphical test. BMJ 1997;315(7109):629-34. doi: 10.1136/bmj.315.7109.629 [published Online First: 1997/10/06]

26. Coppo A, Bellani G, Winterton D, et al. Feasibility and physiological effects of prone positioning in non-intubated patients with acute respiratory failure due to COVID-19 (PRON-COVID): a prospective cohort study. Lancet Respir Med 2020 doi: 10.1016/S2213-2600(20)30268-X [published Online First: 2020/06/23]

27. Damarla M, Zaeh S, Niedermeyer S, et al. Prone Positioning of Non-Intubated Patients with COVID19. Am J Respir Crit Care Med 2020 doi: 10.1164/rccm.202004-1331LE [published Online First: 2020/06/20]

28. Lawton T, Wilkinson KM, Corp A, et al. Reduced ICU demand with early CPAP and proning in COVID-19 at Bradford: a single centre cohort. medRxiv 2020:2020.06.05.20123307. doi: $10.1101 / 2020.06 .05 .20123307$

29. Xu Q, Wang T, Qin X, et al. Early awake prone position combined with high-flow nasal oxygen therapy in severe COVID-19: a case series. Crit Care 2020;24(1):250. doi: 10.1186/s13054-02002991-7 [published Online First: 2020/05/26]

30. Tu GW, Liao YX, Li QY, et al. Prone positioning in high-flow nasal cannula for COVID-19 patients with severe hypoxemia: a pilot study. Ann Transl Med 2020;8(9):598. doi: 10.21037/atm-20-3005 [published Online First: 2020/06/23]

31. Thompson AE, Ranard BL, Wei Y, et al. Prone Positioning in Awake, Nonintubated Patients With COVID-19 Hypoxemic Respiratory Failure. JAMA Intern Med 2020 doi: 10.1001/jamainternmed.2020.3030 [published Online First: 2020/06/26]

32. Sartini C, Tresoldi M, Scarpellini P, et al. Respiratory Parameters in Patients With COVID-19 After Using Noninvasive Ventilation in the Prone Position Outside the Intensive Care Unit. JAMA 2020 doi: 10.1001/jama.2020.7861 [published Online First: 2020/05/16]

33. Retucci M, Aliberti S, Ceruti C, et al. Prone and Lateral Positioning in Spontaneously Breathing Patients With COVID-19 Pneumonia Undergoing Noninvasive Helmet CPAP Treatment. Chest 2020 doi: 10.1016/j.chest.2020.07.006 [published Online First: 2020/07/18]

34. Moghadam VD, Shafiee H, Ghorbani M, et al. Prone positioning in management of COVID-19 hospitalized patients. Braz J Anesthesiol 2020;70(2):188-90. doi: 10.1016/j.bjane.2020.05.001 [published Online First: 2020/05/20]

35. Golestani-Eraghi M, Mahmoodpoor A. Early application of prone position for management of Covid19 patients. J Clin Anesth 2020;66:109917. doi: 10.1016/j.jclinane.2020.109917 [published Online First: 2020/05/31]

36. Elharrar X, Trigui Y, Dols AM, et al. Use of Prone Positioning in Nonintubated Patients With COVID-19 and Hypoxemic Acute Respiratory Failure. JAMA 2020 doi: 10.1001/jama.2020.8255 [published Online First: 2020/05/16] 
medRxiv preprint doi: https://doi.org/10.1101/2020.10.12.20211748; this version posted October 14, 2020. The copyright holder for this preprint

(which was not certified by peer review) is the author/funder, who has granted medRxiv a license to display the preprint in perpetuity.

It is made available under a CC-BY-NC-ND 4.0 International license .

37. Dong W, Gong Y, Feng J, et al. Early Awake Prone and Lateral Position in Non-intubated Severe and Critical Patients with COVID-19 in Wuhan: A Respective Cohort Study. medRxiv 2020:2020.05.09.20091454. doi: 10.1101/2020.05.09.20091454

38. Ferreyro BL, Angriman F, Munshi L, et al. Association of Noninvasive Oxygenation Strategies With All-Cause Mortality in Adults With Acute Hypoxemic Respiratory Failure: A Systematic Review and Meta-analysis. JAMA 2020 doi: 10.1001/jama.2020.9524 [published Online First: 2020/06/05]

39. Group RC, Horby P, Lim WS, et al. Dexamethasone in Hospitalized Patients with Covid-19 Preliminary Report. N Engl J Med 2020 doi: 10.1056/NEJMoa2021436 [published Online First: 2020/07/18]

40. I CIP. COVid-19: A wake Proning and High-flow Nasal Cannula in respiratorY DistrEss (COVAYDE). In: (US) NLoM, ed., 2020.

41. ClinicalTrialsgov [Internet]. McNicholas B LJ. Awake Prone Positioning to Reduce Invasive VEntilation in COVID-19 Induced Acute Respiratory failurE (APPROVE-CARE). In: (US) NLoM, ed., 2020.

42. Ferrando C, Mellado-Artigas R, Gea A, et al. Awake prone positioning does not reduce the risk of intubation in COVID-19 treated with high-flow nasal oxygen therapy: a multicenter, adjusted cohort study. Crit Care 2020;24(1):597. doi: 10.1186/s13054-020-03314-6 [published Online First: 2020/10/08] 
Figure1: PRISMA flowchart of study inclusions and exclusions.

\section{PRISMA 2009 Flow Diagram}
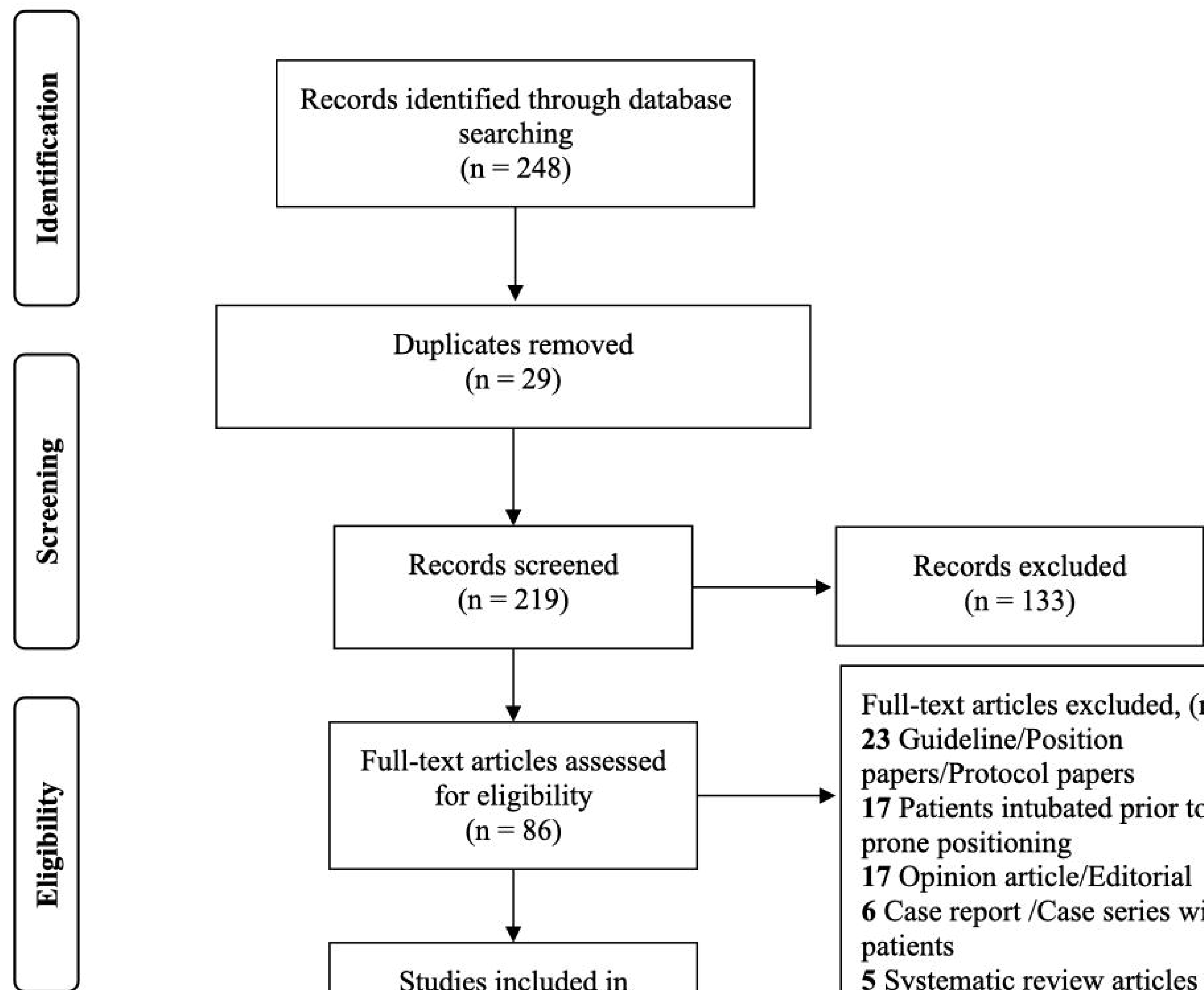

Studies included in qualitative synthesis

Full-text articles excluded, $(\mathrm{n}=71)$ 23 Guideline/Position papers/Protocol papers 17 Patients intubated prior to prone positioning 17 Opinion article/Editorial 6 Case report /Case series with $<5$ patients 5 Systematic review articles 2 COVID PCR Negative 1 No data on primary outcome

From: Moher D, Liberati A, Tetzlaff J, Altman DG, The PRISMA Group (2009). Preferred Reporting /tems for Systematic Reviews and MetaAnalyses: The PRISMA Statement. PLoS Med 6(7): e1000097. doi:10.1371/journal.pmed1000097 
Figure 2: Graphical representation of mean improvements in physiological parameters post-PP

\section{$\mathrm{P} / \mathrm{F}$ ratio}

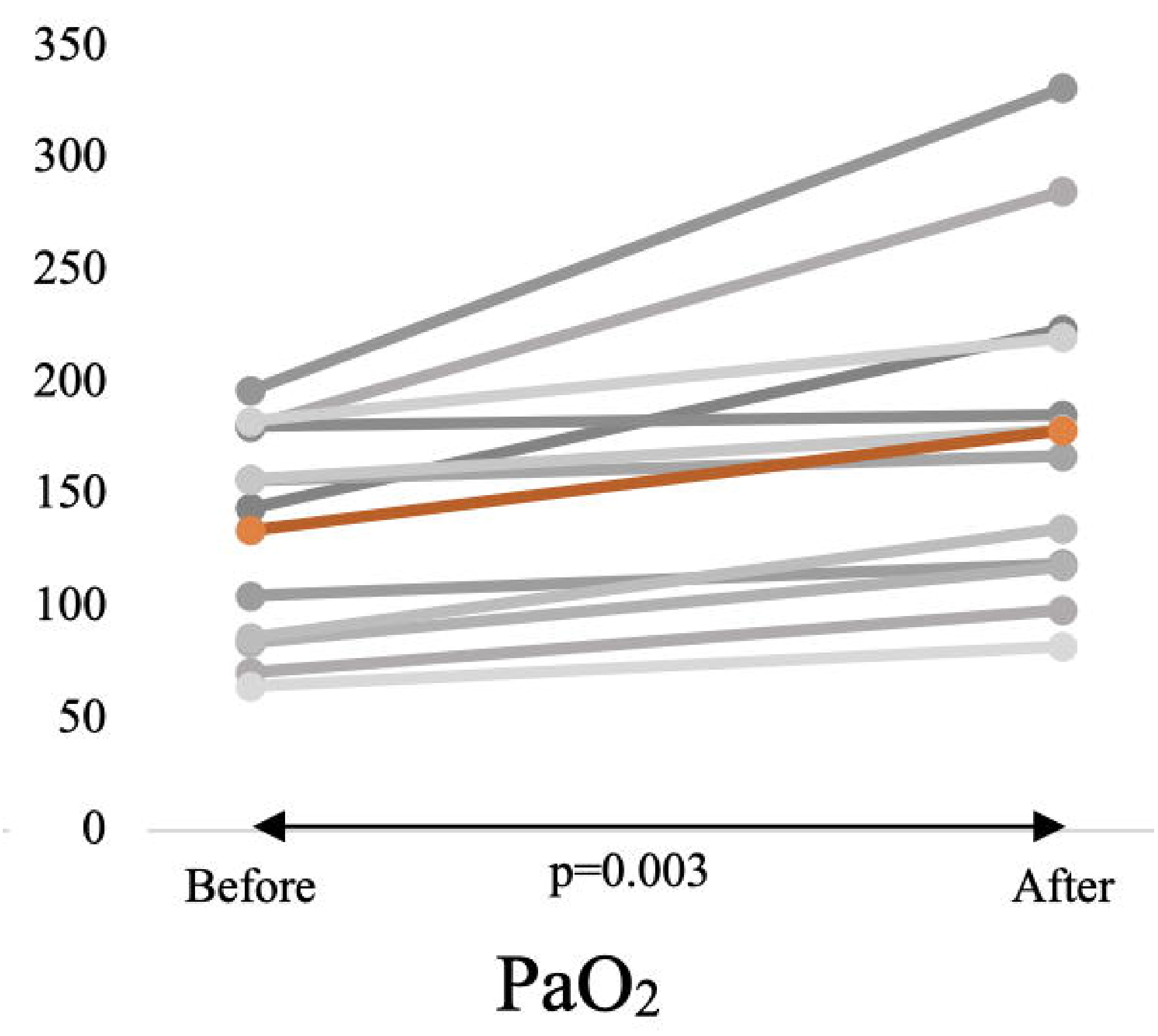

250

200

150

100

50

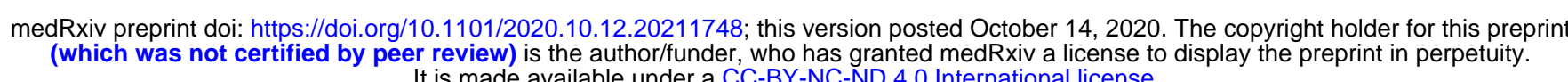

0

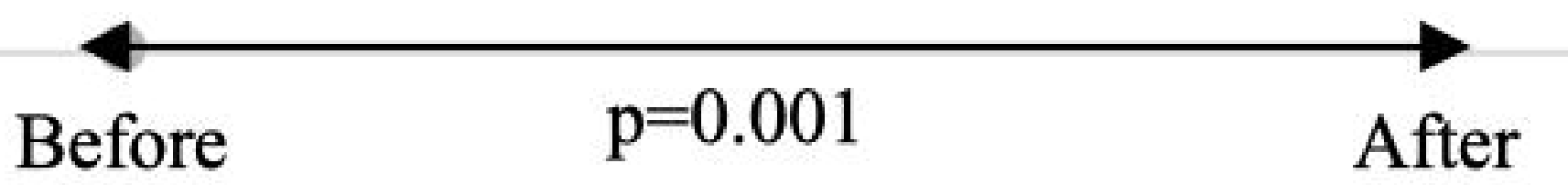

$\mathrm{SpO}_{2}$

100

95

90

85

80

75

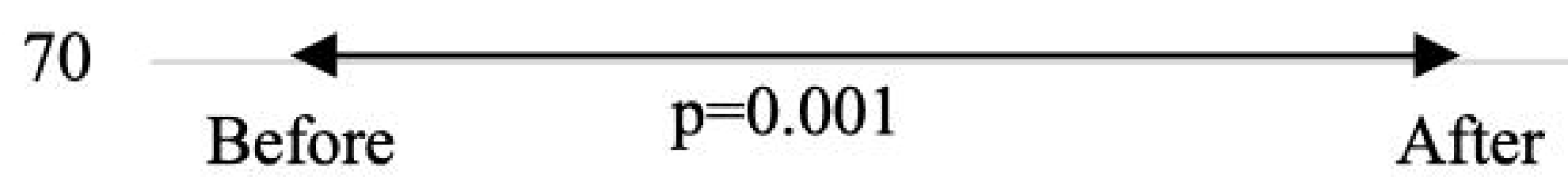


Figure 3: Primary Outcome demonstrating the physiological parameters post-PP

\section{$\mathrm{PaO}_{2} / \mathrm{FiO}_{2}$}

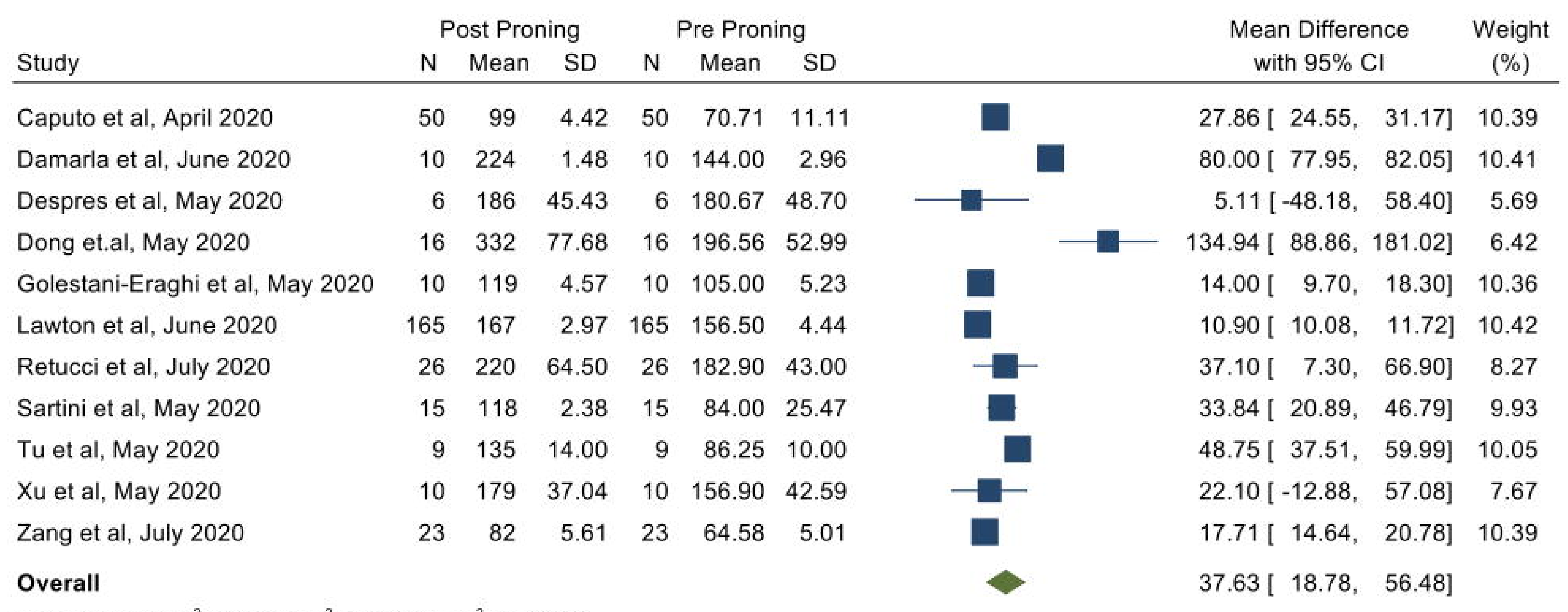

Heterogeneity: $T^{2}=887.74, I^{2}=99.65 \%, H^{2}=288.87$

Test of $\theta=\theta_{j}: Q(10)=3849.84, p=0.00$

Test of $\theta=0: z=3.91, p=0.00$

Random-effects REML model

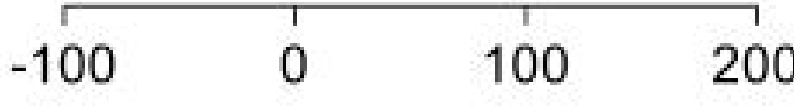

\section{$\mathrm{PaO}_{2}$}

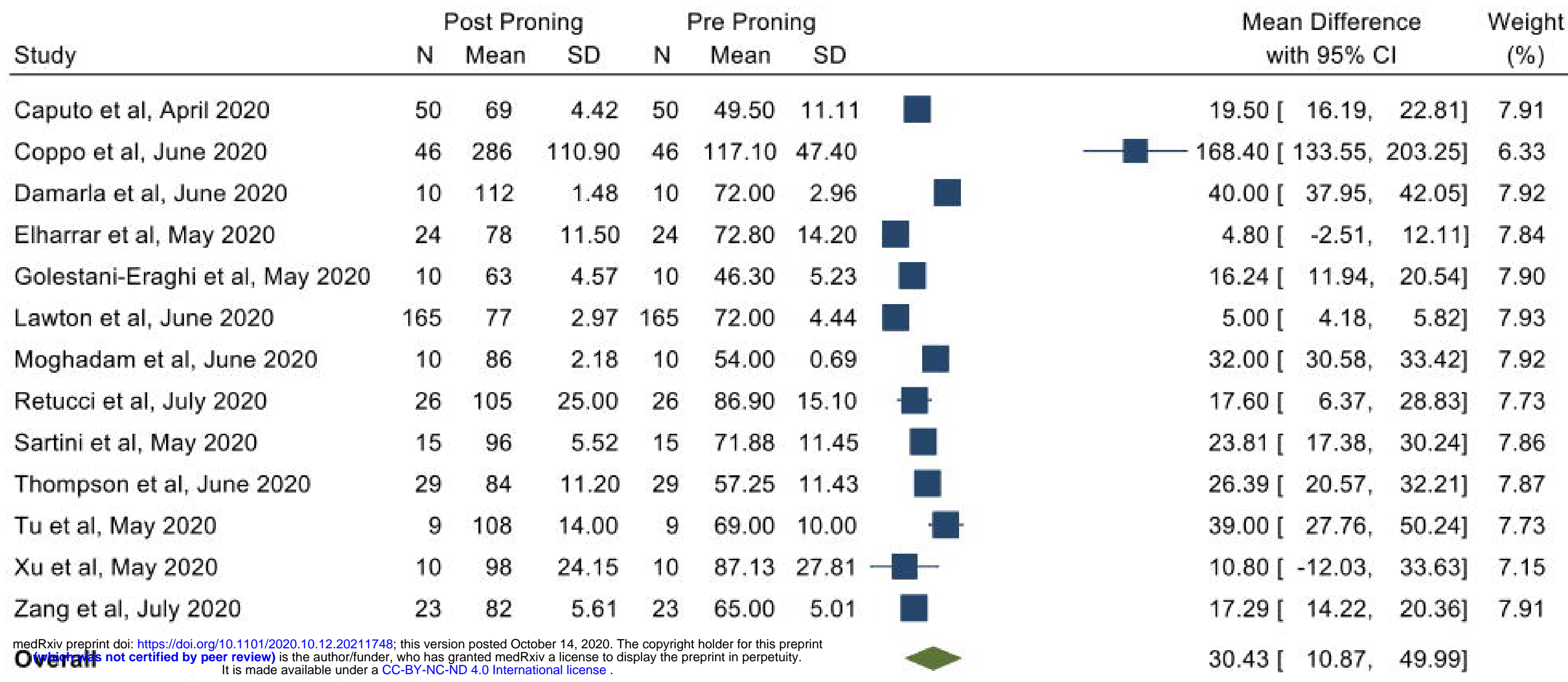

Heterogeneity: $\mathrm{T}^{2}=1256.04, \mathrm{I}^{2}=99.84 \%, \mathrm{H}^{2}=635.50$

Test of $\theta=\theta_{j}: Q(12)=1831.98, p=0.00$

Test of $\theta=0: z=3.05, p=0.00$

$\begin{array}{lllll}0 & 50 & 100 & 150 & 200\end{array}$

Random-effects REML model

$\mathrm{SpO}_{2}$

Post Proning Pre Proning

Mean Difference Weight

Study

$\mathrm{N}$ Mean SD $\mathrm{N}$ Mean SD

with $95 \% \mathrm{Cl}$

(\%)

Caputo et al, April 2020

Damarla et al, June 2020

Elharrar et al, May 2020

$\begin{array}{llllll}50 & 93 & 4.42 & 50 & 83 & 11.11\end{array}$

0.00 [ $6.69,13.31] \quad 8.36$

Golestani-Eraghi et al, May 2020

Lawton et al, June 2020

Moghadam et al, June 2020

Retucci et al, July 2020

Sartini et al, May 2020

Thompson et al, June 2020

Tu et al, May 2020

Xu et al, May 2020

Zang et al, July 2020

$\begin{array}{rrrrrr}10 & 98 & 1.48 & 10 & 93 & 2.96 \\ 24 & 94 & 11.50 & 24 & 93 & 14.20\end{array}$

$\begin{array}{llllll}10 & 91 & 4.57 & 10 & 81 & 5.23\end{array}$

$\begin{array}{llllll}165 & 94 & 2.97 & 165 & 93 & 4.44\end{array}$

$\begin{array}{llllll}10 & 96 & 2.18 & 10 & 86 & 0.69\end{array}$

$\begin{array}{llllll}26 & 98 & 0.74 & 26 & 96 & 2.22\end{array}$

$\begin{array}{llllll}15 & 99 & 1.38 & 15 & 93 & 2.93\end{array}$

$\begin{array}{llllll}29 & 96 & 2.81 & 29 & 87 & 7.14\end{array}$

$\begin{array}{llllll}9 & 96 & 3.00 & 9 & 90 & 2.00\end{array}$

$\begin{array}{llllll}10 & 99 & 24.15 & 10 & 97 & 27.81\end{array}$

$\begin{array}{llllll}23 & 95 & 1.70 & 23 & 91 & 1.50\end{array}$

Overall

Heterogeneity: $\mathrm{T}^{2}=10.89, \mathrm{I}^{2}=94.43 \%, \mathrm{H}^{2}=17.95$

Test of $\theta=\theta_{j}: Q(11)=193.66, p=0.00$

Test of $\theta=0: z=5.42, p=0.00$ 
Figure 4: Secondary Outcomes: Forest plots for rates of intubation and mortality in patients who underwent PP.

\section{Intubation}

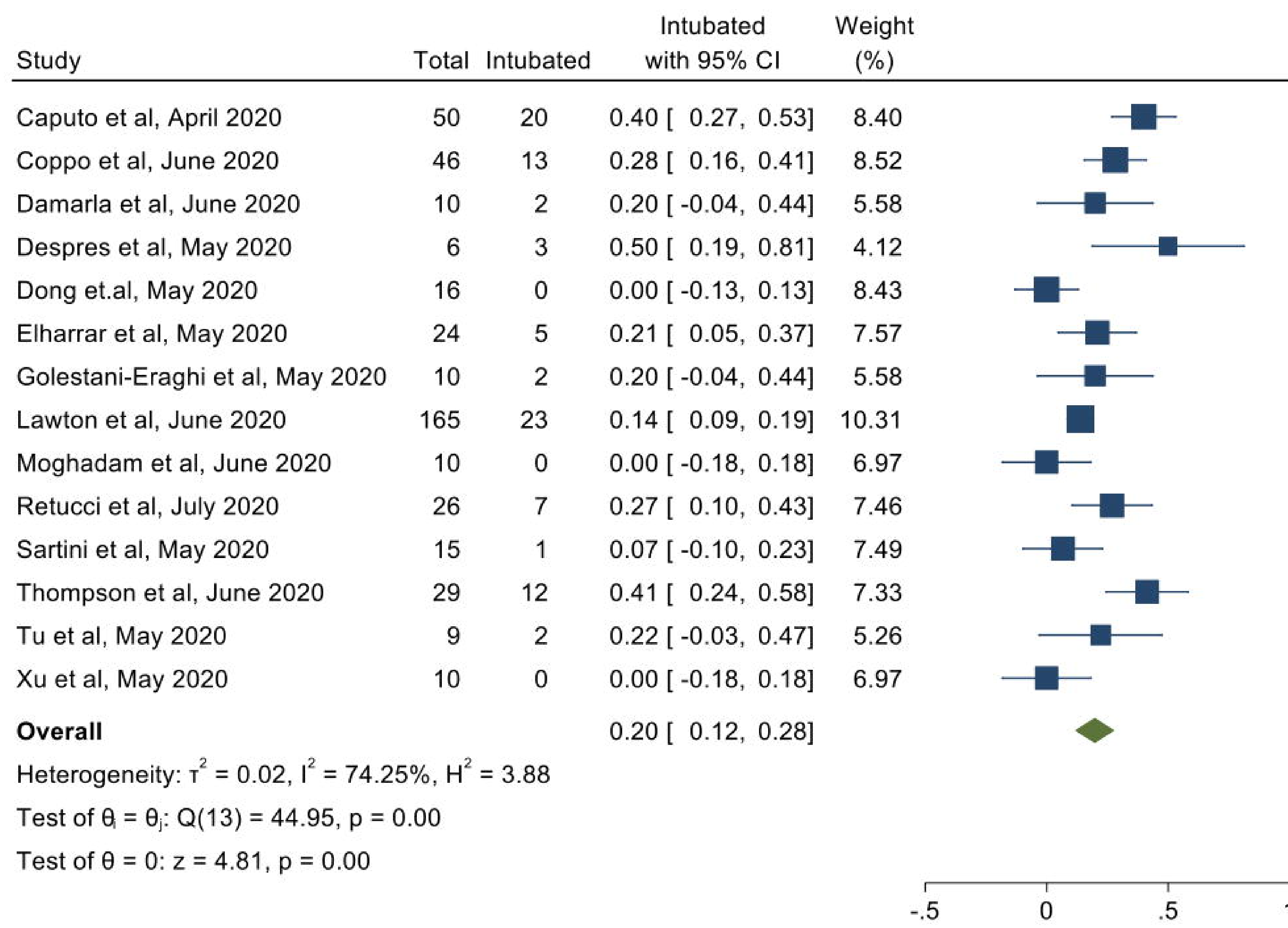

Random-effects REML model

\section{Mortality}

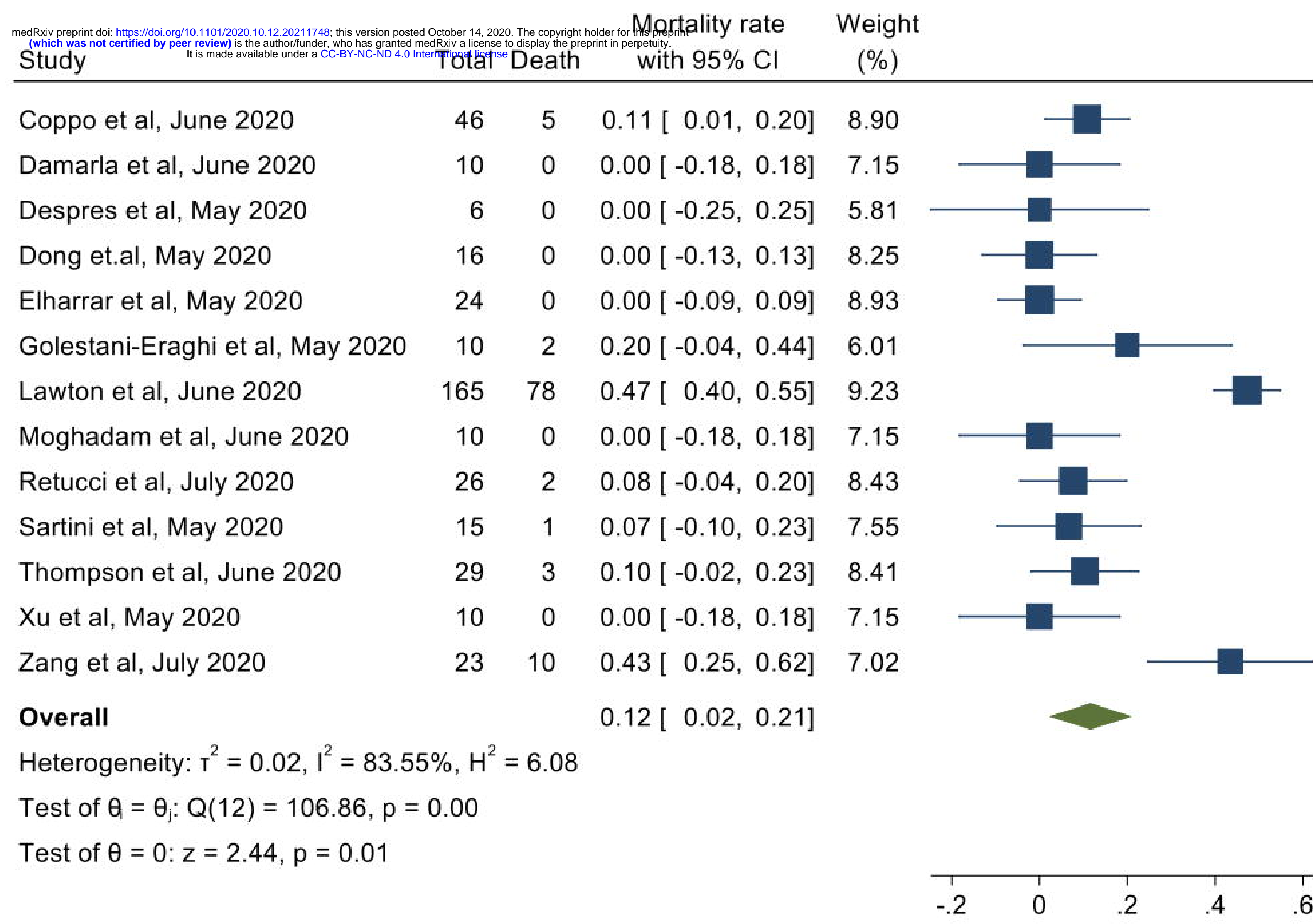


Figure 5: Post hoc analysis based on $\mathrm{P} / \mathrm{F}$ ratio demonstrate that $\mathrm{PaO}_{2} / \mathrm{FiO}_{2}$ $\leq 150$ pre-PP had statistically significant improvements when compared with $\mathrm{PaO}_{2} / \mathrm{FiO}_{2}>150$

\section{$\mathrm{PaO}_{2} / \mathrm{FiO}_{2}>150$}

\begin{tabular}{|c|c|c|c|c|c|c|c|c|c|}
\hline \multirow[b]{2}{*}{ Study } & \multicolumn{3}{|c|}{ Post Proning } & \multicolumn{3}{|c|}{ Pre Proning } & & \multirow{2}{*}{$\begin{array}{c}\text { Mean Difference } \\
\text { with } 95 \% \mathrm{Cl}\end{array}$} & \multirow{2}{*}{$\begin{array}{c}\text { Weight } \\
(\%)\end{array}$} \\
\hline & $\mathrm{N}$ & Mean & SD & $\mathrm{N}$ & Mean & SD & & & \\
\hline Despres et al, May 2020 & 6 & 186 & 45.43 & 6 & 180.67 & 48.70 & - & $5.11[-48.18$ & 17.28 \\
\hline Dong et.al, May 2020 & 16 & 332 & 77.68 & 16 & 196.56 & 52.99 & & $134.94[88.86,181.02]$ & 18.46 \\
\hline Lawton et al, June 2020 & 165 & 167 & 2.97 & 165 & 156.50 & 4.44 & & $10.90[10.08$ & 23.14 \\
\hline Retucci et al, July 2020 & 26 & 220 & 64.50 & 26 & 182.90 & 43.00 & & 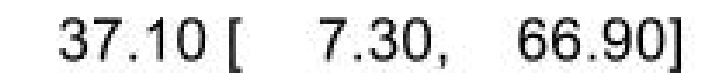 & 20.92 \\
\hline Xu et al, May 2020 & 10 & 179 & 37.04 & 10 & 156.90 & 42.59 & 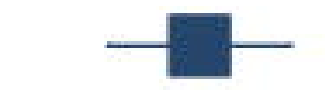 & 22.10 [ -12.88, & 20.19 \\
\hline Overall & & & & & & & & 40.54 [ -3.49, & \\
\hline
\end{tabular}

Heterogeneity: $\mathrm{T}^{2}=2180.67, \mathrm{I}^{2}=92.05 \%, \mathrm{H}^{2}=12.57$

Test of $\theta_{1}=\theta_{j}: Q(4)=31.23, p=0.00$

Test of $\theta=0: z=1.80, p=0.07$

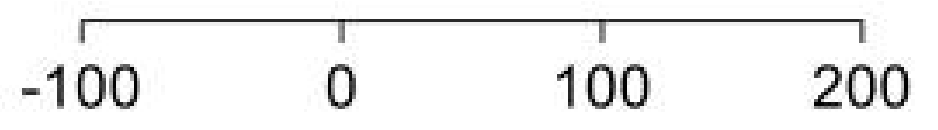

Random-effects REML model

\section{$\mathrm{PaO}_{2} / \mathrm{FiO}_{2} \leq 150$}

\begin{tabular}{|c|c|c|c|c|c|c|c|c|}
\hline \multirow[b]{2}{*}{ Study } & \multicolumn{3}{|c|}{ Post Proning } & \multicolumn{3}{|c|}{ Pre Proning } & \multirow{2}{*}{$\begin{array}{c}\text { Mean Difference } \\
\text { with } 95 \% \mathrm{Cl}\end{array}$} & \multirow{2}{*}{$\begin{array}{c}\text { Weight } \\
(\%)\end{array}$} \\
\hline & $\mathrm{N}$ & Mean & SD & $\mathrm{N}$ & Mean & SD & & \\
\hline Caputo et al, April 2020 & 50 & 99 & 4.42 & 50 & 70.71 & 11.11 & $27.86[24.55,31.17]$ & 16.98 \\
\hline Damarla et al, June 2020 & 10 & 224 & 1.48 & 10 & 144.00 & 2.96 & $80.00[77.95,82.05]$ & 17.03 \\
\hline Golestani-Eraghi et al, May 2020 & 10 & 119 & 4.57 & 10 & 105.00 & 5.23 & $14.00[9.70,18.30]$ & 16.92 \\
\hline Sartini et al, May 2020 & 15 & 118 & 2.38 & 15 & 84.00 & 25.47 & $33.84[20.89,46.79]$ & 15.91 \\
\hline Tu et al, May 2020 & 9 & 135 & 14.00 & 9 & 86.25 & 10.00 & $48.75[37.51,59.99]$ & 16.18 \\
\hline Zang et al, July 2020 & 23 & 82 & 5.61 & 23 & 64.58 & 5.01 & $17.71[14.64,20.78]$ & 16.99 \\
\hline Overall & & & & & & & $37.00[17.11,56.88]$ & \\
\hline
\end{tabular}

Heterogeneity: $\mathrm{T}^{2}=603.45, \mathrm{I}^{2}=99.38 \%, \mathrm{H}^{2}=161.03$

Test of $\theta_{1}=\theta_{j}: Q(5)=1690.85, p=0.00$

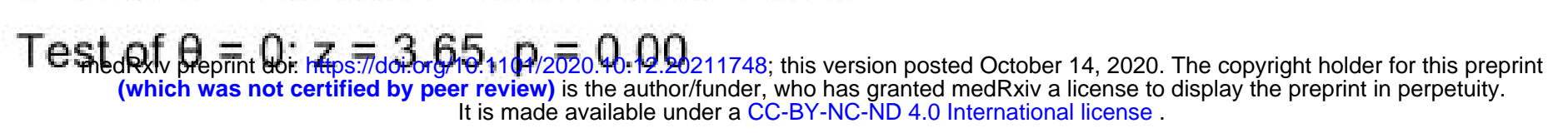

Random-effects REML model 